\title{
1,2-Diaza-1,3-butadienes; just a nice class of compounds, or powerful tools in organic chemistry? Reviewing an experience
}

\author{
Orazio A. Attanasi, Lucia De Crescentini, Paolino Filippone," Fabio Mantellini, \\ and Stefania Santeusanio* \\ Istituto di Chimica Organica, Università di Urbino, Piazza della Repubblica 13, 61029 Urbino, \\ Italy \\ E-mail: $\underline{\text { attanasi@uniurb.it }}$
}

\section{Dedicated to Professor Domenico Spinelli on his $70^{\text {th }}$ birthday}

(received 18 Nov 02; accepted 20 Jan 03; published on the web 28 Jan 03)

\begin{abstract}
This paper reviews our nearly twenty-five years' activity on 1,2-diaza-1,3-butadienes and shows that these compounds are powerful tools in organic chemistry. In fact, $\alpha$-substituted-, $\alpha$-oxo-, and $\alpha, \beta$-unsaturated-hydrazones, have been obtained from 1,2-diaza-1,3-butadienes, as have pyrroles, pyrazoles, imidazoles, thiazoles, selenazoles, 1,2,3-thiadiazoles, 1,2,3-selenadiazoles, pyridazines, pyrazines, 1,2,4-triazines, and mixed heterocyclic systems.
\end{abstract}

Keywords: 1,2-Diaza-1,3-butadienes, 1,4-addition, hydrazones, heterocycles

\section{Topic and nomenclature}

This account deals with our contributions to the chemistry of compounds bearing an azo group adjacent to an aliphatic double bond (Figure 1).<smiles>[R]C=C([R])NN[R1]</smiles>

\section{Figure 1}

These compounds may be called enyldiazenes (IUPAC), 1,2-diaza-1,3-butadienes or, commonly, conjugated azo-alkenes or azo-olefins. Here, we use the name 1,2-diaza-1,3-butadienes (DBD). 


\section{History}

Their yellow, orange, red or amaranth colors, ascribable to the conjugation, and frequently the beautiful crystal forms, make DBD an attractive class of compounds.

The DBD may be considered part of the large family of hydrazine derivatives. However, owing to the difficulty of spectroscopic analysis, the restricted diversity of structures, and the problematic stability of some derivatives, DBD were long considered not to be amenable to important development, and were therefore not extensively investigated up to the end of the 1960s. In fact, only a modest number of papers had appeared in the literature until this date. Over the last thirty years, the investigations have increased drastically, showing the usefulness of these compounds in organic chemistry. ${ }^{1-5}$

We started our investigations at the end of the 1970s, hardly believing that our adventure would continue for nearly twenty-five years.

\section{Synthesis}

DBD are synthesized, also as polymer-bound substrates, by base-treatment of hydrazone derivatives bearing a leaving group in the $\alpha$-position to the $>\mathrm{C}=\mathrm{N}$ - moiety. Two different routes are possible: (i) the hydrazone derivatives are prepared from carbonyl compounds bearing the leaving group; (ii) the leaving group is introduced in the $\alpha$-position of the hydrazone function (Scheme 1). Sometimes, DBD are generated in situ. Currently, DBD are obtained and used as their $E, E-E, Z$ isomeric mixtures. Other methods are of limited preparative value. ${ }^{1-28}$

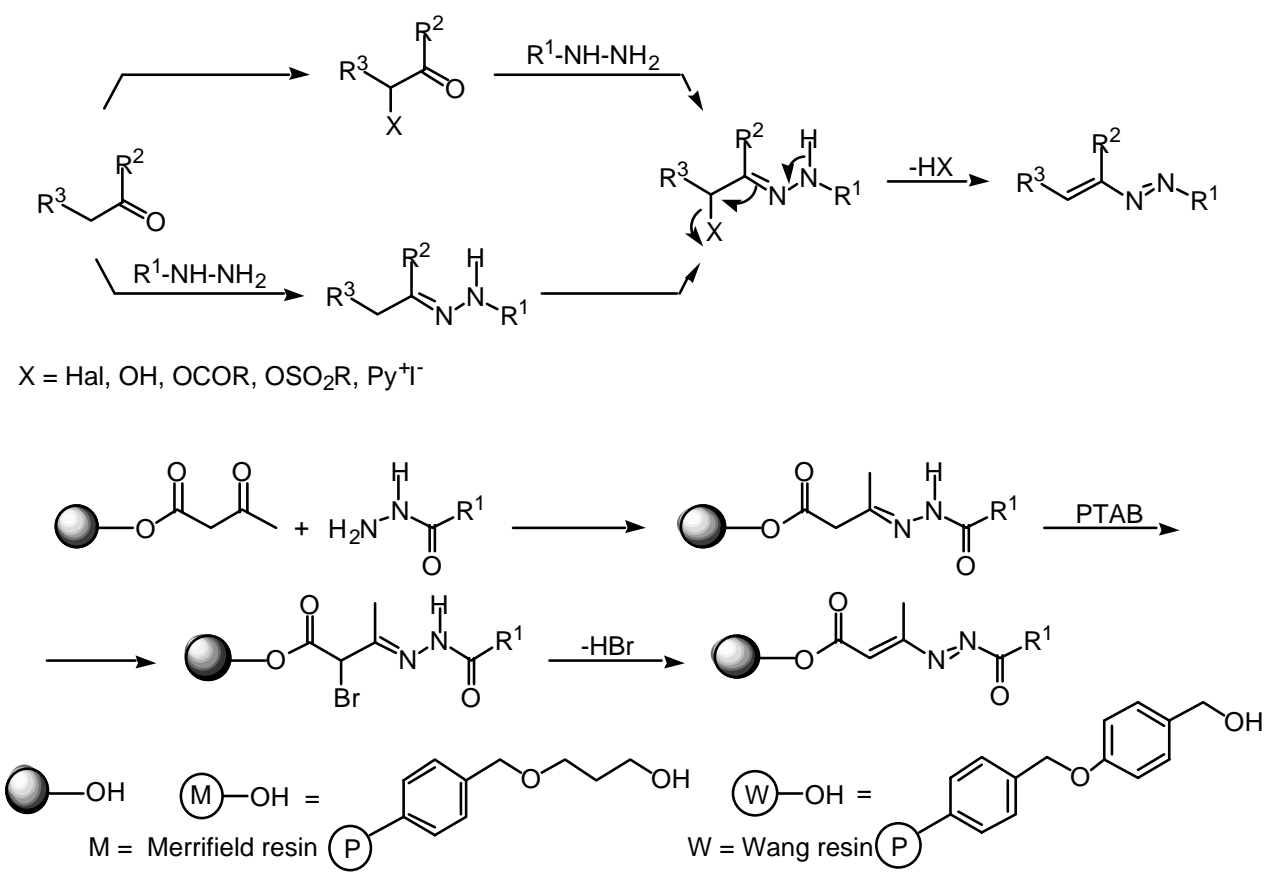

\section{Scheme 1}




\section{Properties}

The chemical properties of DBD are related to: (i) the conjugated heterodiene system, and, (ii), the substituents on the carbon and nitrogen atoms. The former is comparable with a conjugated homo-diene system (for 1,4-conjugate additions and Diels-Alder [4+2], [3+2] or [2+2] cycloadditions). However, the electron-withdrawing effect of the azo group enhances the reactivity of the heterodiene system with respect to that of a homo-diene system, especially towards regioselective nucleophilic attacks at the terminal carbon. Furthermore, the presence of the azo group imparts behavior (interconversion of azo- and hydrazo forms, the formation of the hydrazono moiety, and the hydrazino-hydrazono interconversion), and reactions typical of hydrazine derivatives of carbonyl compounds (inter- and intra-molecular nucleophilic attack by both nitrogens). The latter influences both the stability and reactivity of DBD. In general, electron-poor substituents (e.g., ester or amide groups) on terminal carbon and/or nitrogen favor both the stability and the regioselective nucleophilic attacks at the terminal carbon, and permit further interesting reactions of the hydrazone 1,4-adduct intermediate. Aryl groups favor the stability but not the reactivity, mainly owing to the absence of functionalities which are useful for further reactions, while alkyl groups or terminal $\mathrm{C}=\mathrm{C}$ bonds do not favor stability, and give rise to reactions with DBD by-products. ${ }^{1-28}$

\section{Reactions}

Our work has mainly dealt with the easy regioselective nucleophilic attack at the terminal carbon of the heterodiene system of DBD by a variety of carbon- and hetero-nucleophiles that represents the first remarkable goal of this class of compounds. In fact, this attack produces $\alpha$ functionalized hydrazones by 1,4-addition (Michael-type) of nucleophilic reagents with the formation of new carbon-carbon or carbon-heteroatom bonds. It is noteworthy that the carbon target is in the $\alpha$-position to the carbonyl group from which DBD are prepared, and it is well known that such a carbon is inclined to react with electrophilic rather than nucleophilic agents.

Although the hydrazone intermediates were not always isolable, in general three main reaction pathways are possible: (i) the production of $\alpha, \beta$-unsaturated hydrazones when the attacking nucleophiles bear leaving groups (in particular cases, the carbon-heteroatom double bond formation was also observed); (ii) heterocycle formation with "closing" groups on the attacking nucleophiles by different [2+2], [3+2], and [4+2] annulations; (iii) heterocycle formation with "closing" groups present on the former DBD molecule. In these last two processes, both nitrogens can be operative (Scheme 2). Other collateral and/or subsequent reactions (i.e., oxidation of the carbon in the $\alpha$-position to the hydrazono moiety, cleavage of hydrazino/hydrazono groups with production of $\alpha$-substituted carbonyl compounds, cleavage of $\mathrm{N}-\mathrm{C}$ and/or $\mathrm{N}-\mathrm{N}$ bonds), enrich the chemistry of the title compounds.

These reactions do not require anhydrous solvents or inert atmospheres, and generally occur under mild conditions and need only simple work-up procedures. Although most of these 
reactions formally proceed through a number of chemical steps, they can frequently be executed in one pot.

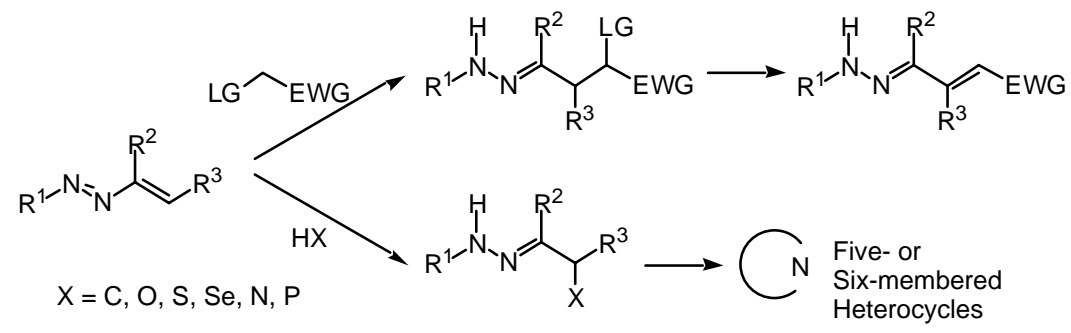

\section{Scheme 2}

\section{Carbon-carbon single and double bonds}

The DBD, 1, give $\alpha$-functionalized hydrazones 3 with the formation of a single carbon-carbon bond by the addition of activated methylene or methyne compounds, 2 , i.e., $\beta$-diketones, $\beta$ triketones, $\beta$-keto esters, $\beta$-diketo esters, ${ }^{15,17-19,22,25,29-45}$ pyrazolinones, ${ }^{23} \beta$-amido esters, ${ }^{22,26}$ $\beta$-keto lactones, ${ }^{37} \beta$-keto amides, barbituric acid, ${ }^{8-10,18,22,26,38,45-49} \beta$-keto sulfones, ${ }^{50-52} \beta$-ester phosphoranes, ${ }^{53,54} \beta$-keto phosphoranes, ${ }^{55}$ malononitrile, ${ }^{56,57} \beta$-cyano amides, cyanoacetyl hydrazones, ${ }^{22,57,58} \beta$-cyano esters, ${ }^{19,56,59} \beta$-cyano ketones, ${ }^{19,58,59}$ remotely activated ketones, esters, nitriles, ${ }^{18,26,44,45,57,60} \beta$-nitro ketones, $\beta$-nitro esters, ${ }^{61} \beta$-keto phosphonates, ${ }^{62} \beta$-cyano phosphonates, ${ }^{57,62}$ Meldrum's acids, ${ }^{44,45,63} \beta$-ester phosphonates, ${ }^{38,64} \beta$-diesters, $\beta$ triesters, ${ }^{17,19,27,44,45,65,66} \beta$-cyano sulfones, $\beta$-nitro sulfones, $\beta$-disulfones, $\beta$-amido sulfones, $\beta$ ester sulfones, $\quad \beta$-ester sulfines, ${ }^{67}$ bromonitromethane, halomalonates, $\alpha, \alpha$ dichloroacetophenone, ${ }^{68}$ and aldehydes. ${ }^{69}$ The mono-1,4-adducts, 3, still having an active hydrogen $\left(\mathrm{R}^{6}=\mathrm{H}\right)$, can provide the bis-1, 4-adducts, 4 , by further 1,4-addition of the same or different $\mathrm{DBD}$ molecule $\left(\mathrm{R}^{1}, \mathrm{R}^{2}, \mathrm{R}^{3}=\right.$ or $\left.\neq \mathrm{R}^{1}, \mathrm{R}^{2}, \mathrm{R}^{3}\right) .{ }^{27,56,58,62}$ In the case of triphenylphosphine, ${ }^{53-55}$ nitro-, ${ }^{61,67}$ phenylsulfonyl-, $p$-chlorophenylsulfonyl-, $p$-toluenesulfonyl, phenylsulphinyl-, ${ }^{67}$ and halogen- 68 derivatives in which $\mathrm{R}^{4}$ is a leaving group, $\alpha, \beta$-unsaturated hydrazones, 5, were obtained (Scheme 3).

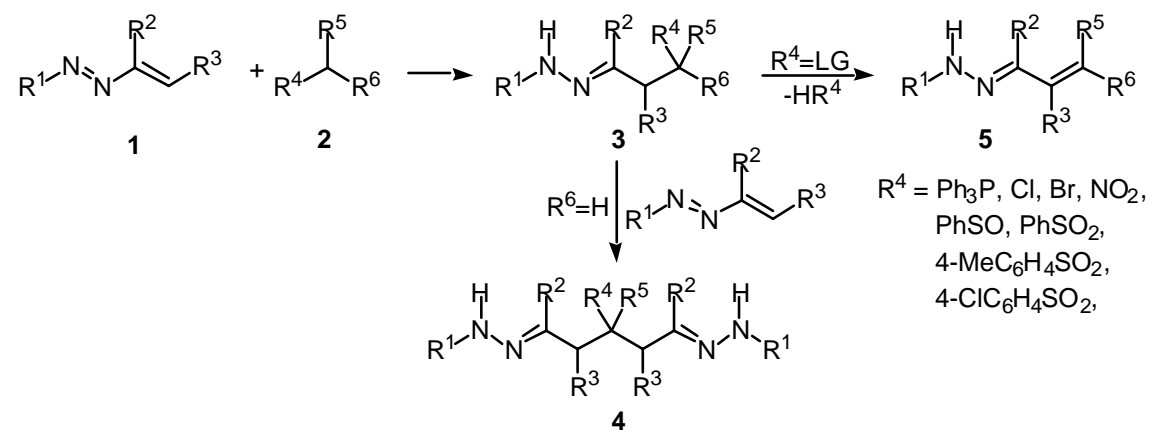

\section{Scheme 3}




\section{Carbon-heteroatom single and double bonds}

A single carbon-heteroatom bond is achieved by treatment of DBD, 1, with alcohols, ${ }^{70-72}$ phenols, ${ }^{71,72}$ mercaptans, ${ }^{72-74}$ thio acids, ${ }^{75}$ thioamides, thioureas, selenoamides, selenoureas, ${ }^{21,24,25,28,74,76}$ amines, imides, ${ }^{77-81}$ sulfonamides, ${ }^{82}$ and hydrazine derivatives $\mathbf{6} .61,82-$ 85 This 1,4-addition yields the relevant hydrazones, 7 , frequently in tautomeric equilibrium with the corresponding hydrazino forms, 8 , (Scheme 4). ${ }^{75,82,83}$

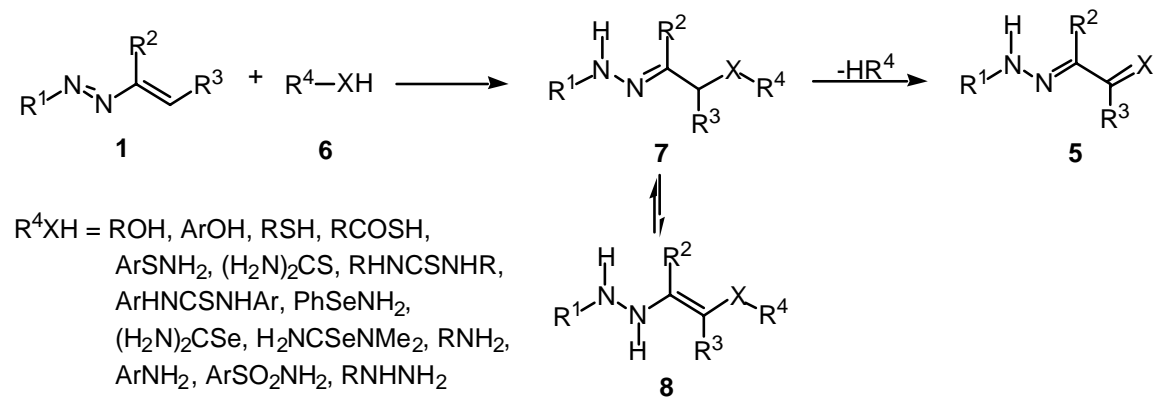

\section{Scheme 4}

Phosphine- $86-88$ and nitroso- 89 derivatives add to the conjugate azo-ene moiety of DBD 1 to initially produce the corresponding 1,5-zwitterionic intermediates, $\mathbf{9}$ and 11, respectively, that then tautomerize into the respective hydrazones, 10 and 12, respectively (Scheme 5).

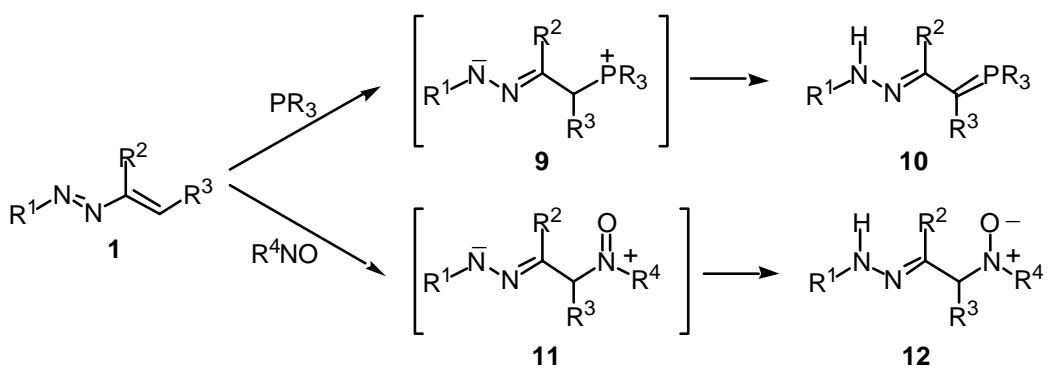

\section{Scheme 5}

\section{Heterocycles}

To date, pyrroles, pyrazoles, imidazoles, thiazoles, selenazoles, 1,2,3-thiadiazoles, 1,2,3selenodiazoles, pyridazines, pyrazines, 1,2,4-triazines, and mixed heterocyclic systems, have been obtained from DBD (Scheme 6).

2-Hydroxy-1-aminopyrrolines, 14, and 1-aminopyrroles, 15, were synthesized by reaction of DBD, 1, with $\beta$-diketones, $\beta$-keto esters, ${ }^{15,17,18,22,29-39,42,43,67,90} \beta$-keto amides, ${ }^{8-}$ 10,18,22,28,38,46-49,67 $\beta$-keto lactones, ${ }^{37} \beta$-keto phosphoranes, ${ }^{55} \beta$-nitro ketones, ${ }^{61,67} \beta$-keto 
sulfones, ${ }^{50-52,67} \beta$-cyano ketones, ${ }^{58,59,67}$ remotely activated ketones, ${ }^{60} \beta$-keto phosphonates, ${ }^{62}$ $\alpha, \alpha$-dichloroacetophenone, $\mathbf{1 3},{ }^{68}$ and aldehydes. ${ }^{69}$

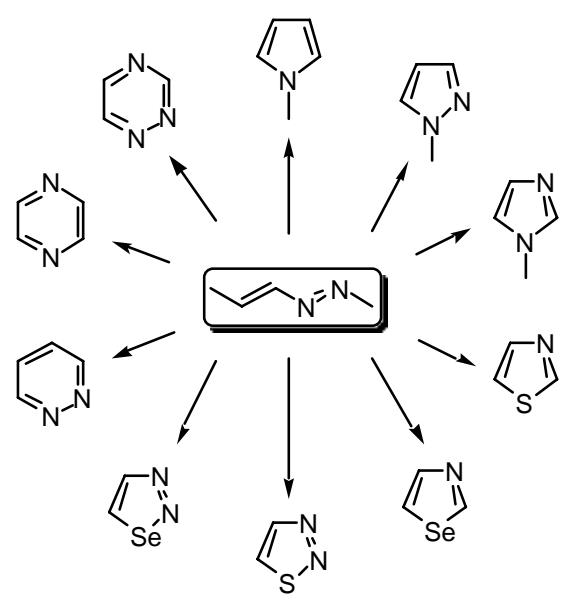

\section{Scheme 6}

The reaction between DBD and 2-chloro-1,3-dicarbonyl compounds was erroneously reported to give 1-amino-2-chloromethylene-2,3-dihydropyrroles, instead of 2-(chloromethyl)-1aminopyrroles. ${ }^{39}$ In these cases, DBD participates with the $\mathrm{N}(1)-\mathrm{C}(2)-\mathrm{C}(3)$ part, while the carbonyl compounds put in place the $\mathrm{C}(4)-\mathrm{C}(5)$ part with the final [3+2] cyclization (Scheme 7). ${ }^{91-95}$ The variety of pyrroles 15 synthesized is shown in Scheme 7.

The DBD, 1, react with $\beta$-diesters, ${ }^{27,65,66}$ Meldrum's acids, ${ }^{63} \beta$-cyano esters, ${ }^{59} \beta$-ester phosphonates, ${ }^{38,64}$ or $\beta$-ester phosphoranes, providing 1-aminopyrrolin-2-ones, 16, by [3+2] cyclization similar to that shown above (Scheme 8). ${ }^{54}$ Symmetrical and unsymmetrical spiro compounds, 17, resulted by double conjugated addition of malonate to $\mathrm{DBD}$, followed by double cyclization.

1,2-Diaminopyrroles, 19, and pyrrolo[2,3-b]pyrroles, 20, were furnished by treatment of DBD, 1, with malononitrile, ${ }^{56,57} \beta$-cyano esters, ${ }^{56} \beta$-cyano ketones, ${ }^{58} \beta$-cyano amides, ${ }^{57,58,90}$ remotely activated nitriles, ${ }^{57,60}$ and $\beta$-cyanophosphonates, ${ }^{57,62} \mathbf{1 8}$, in equimolar ratio or in molar excess, respectively, through [3+2] annulation on the same cyano function. Examples of complex heterocycle structures derived from diaminopyrroles 19 are also shown in Scheme 9. 


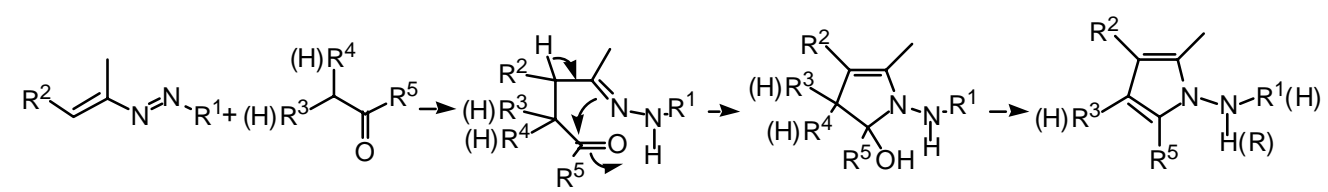

13

14

15

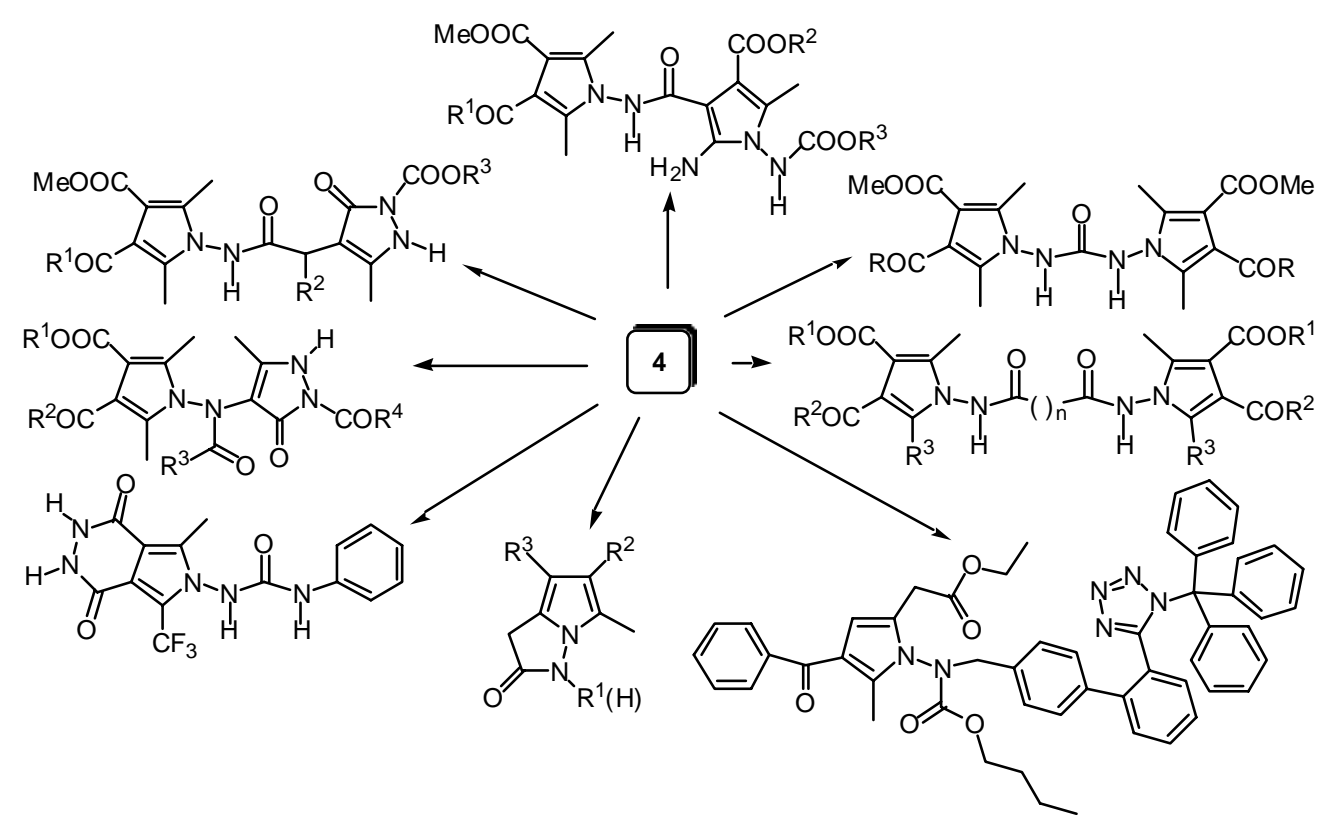

Scheme 7

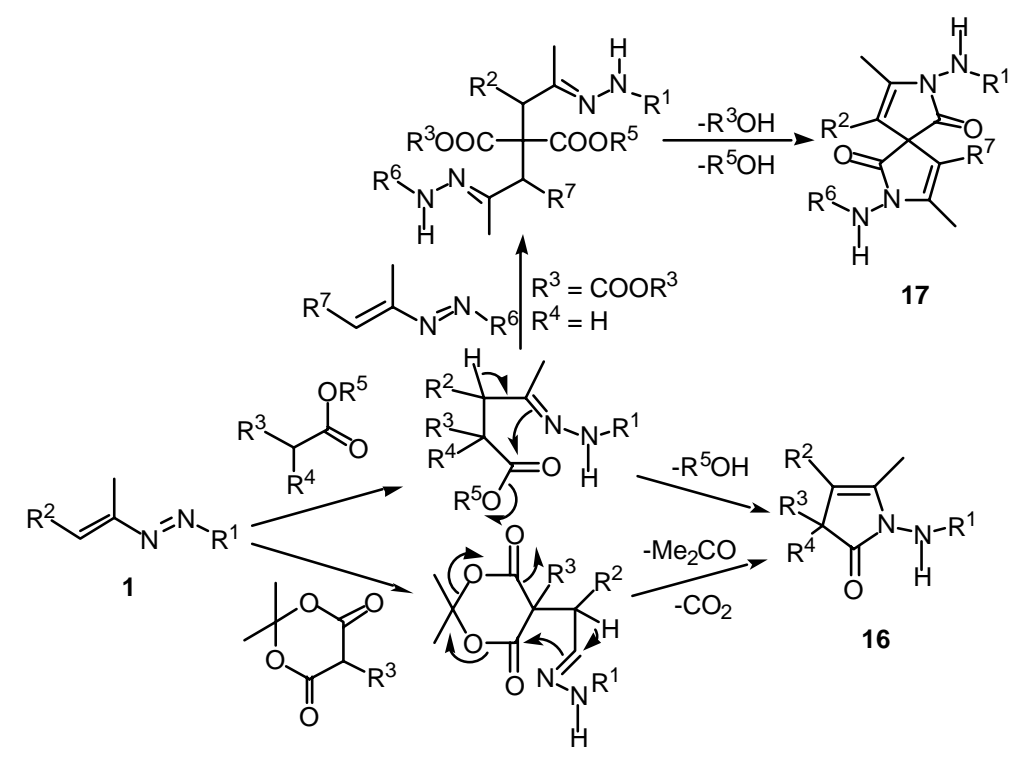

\section{Scheme 8}




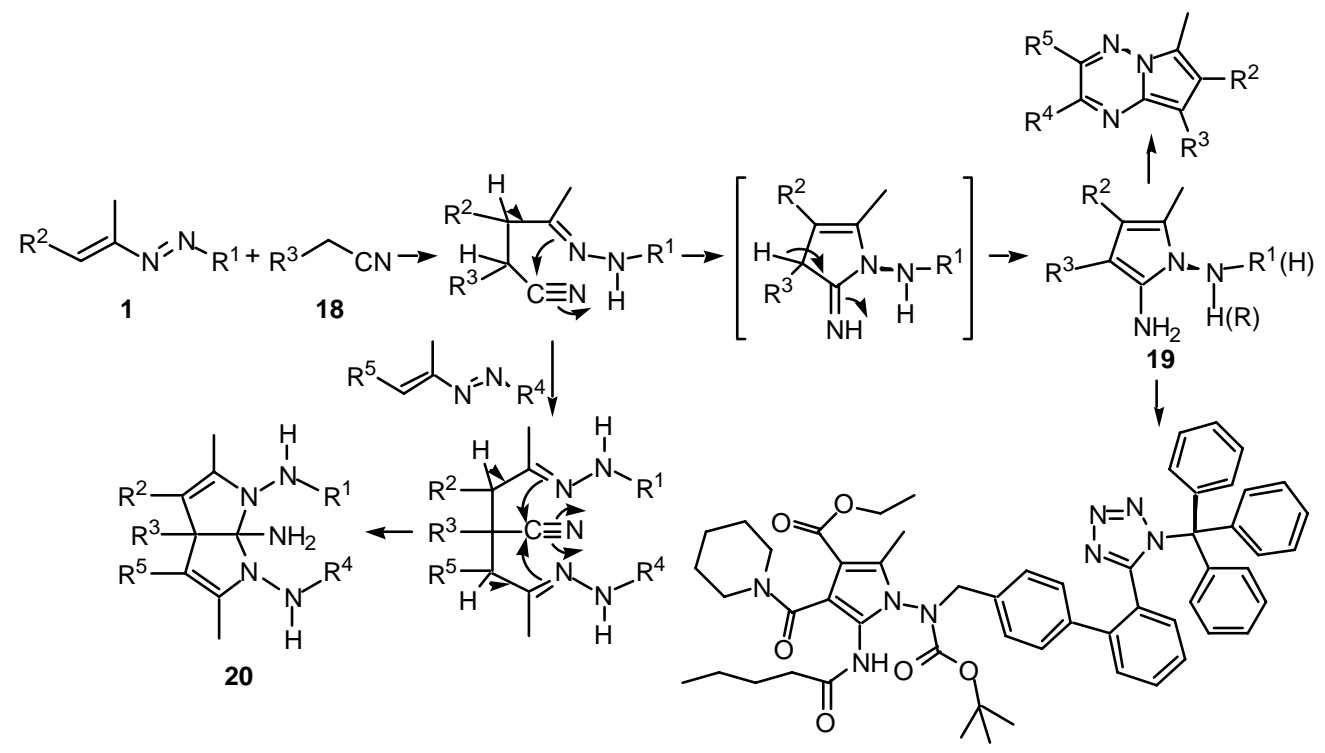

\section{Scheme 9}

When the nucleophiles 21 bear no group able to permit the closure of a pyrrole ring, an internal nucleophilic attack of the terminal hydrazone nitrogen at the carboxylate group in the $\gamma$ position of the 1,4-adduct intermediate, 22, takes place giving pyrazolin-5-ones, 23, in their NH$\mathrm{CH}$ tautomeric forms, by an intramolecular cyclization. ${ }^{16,20,23,28,66,72,73,75,78,79,82,85}$ Quite different pyrazolinones, 24 and 25, were isolated from 1,4-adduct intermediates between DBD and phosphine $28,86,88$ or nitroso 89 derivatives, respectively (Scheme 5). In these cases, the attacking nucleophiles represent the functionalities in position 4 (Scheme 10).

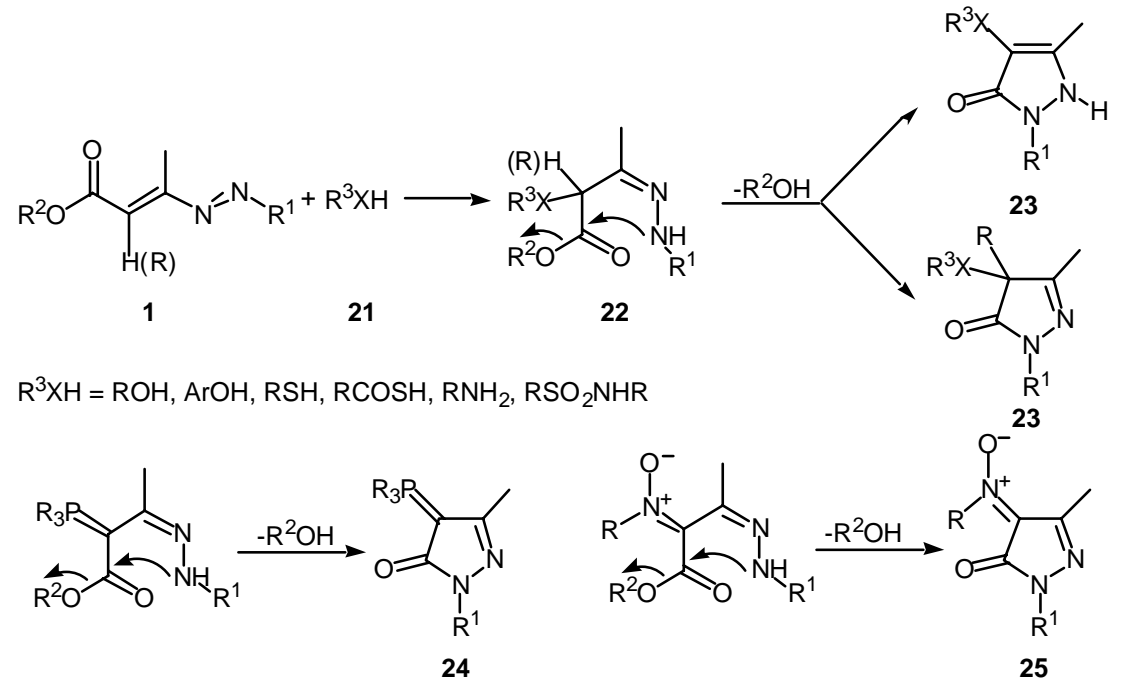

Scheme 10 
The pyrazoles 27 and 30 were obtained by reaction of DBD, 1, with 2-phenylazo-1,3dicarbonyl compounds, ${ }^{41} \mathbf{2 6}$, or arylchlorodiazirines, 29, via arylchlorocarbenes. ${ }^{94}$ The pyrazolopyridazinones, 28, were prepared from the pyrazoles, 27 (Scheme 11). ${ }^{41}$ Pyrazoles were also reached by treatment of DBD with triphenylphosphine, ${ }^{16,86,87}$ thiocarboxylic acids, ${ }^{75}$ and $\beta$ tricarbonyl compounds. ${ }^{17}$

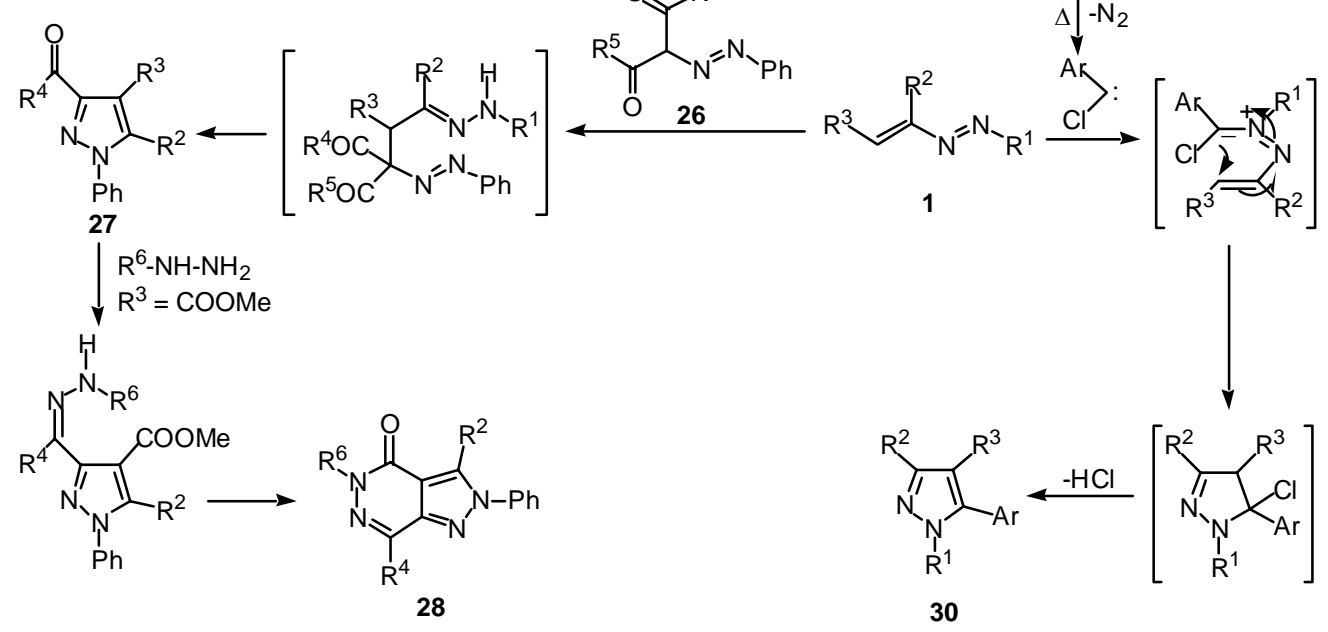

\section{Scheme 11}

The $\alpha$-aminohydrazones, 31, produced by addition of amines to DBD, 1, afford the pyrazolinones, 32, under basic conditions or imidazolines, 33, and then imidazoles, 34, under oxidative conditions (Scheme 12). ${ }^{78-80}$

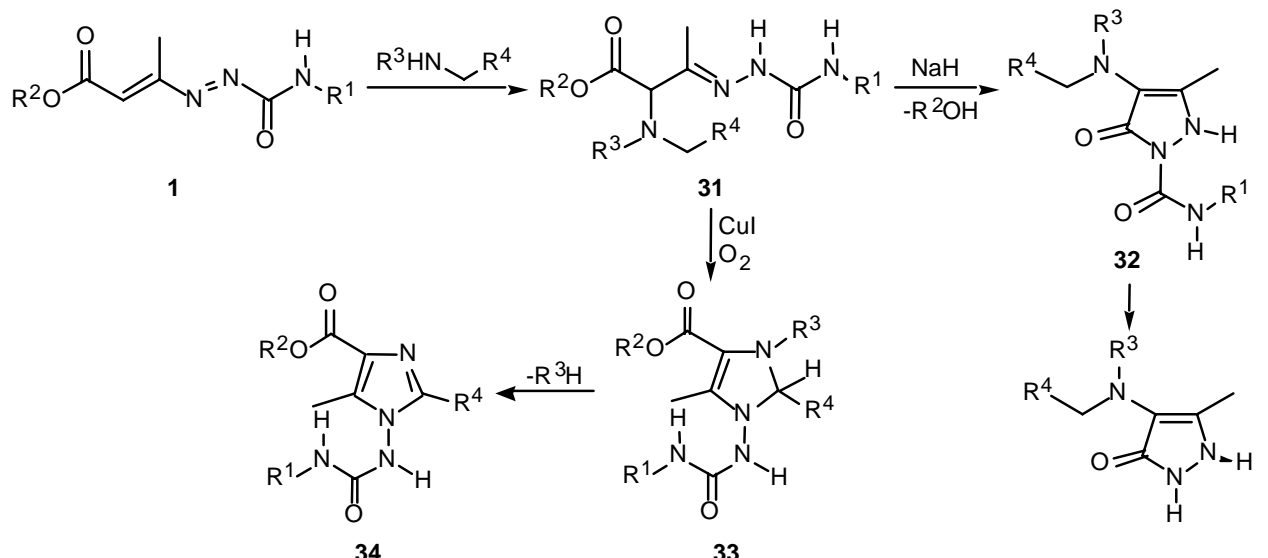

Scheme 12 
The reaction between DBD, 1, and thioamides or the thioureas 35 produces thiazolin-4-ones, 36, in hydrazino-hydrazono tautomeric equilibrium, by a [3+2] cyclization different from that of pyrroles. In fact, the preliminary attack by sulfur at the usual carbon involves the subsequent imino attack at the ester group on the terminal carbon. So, DBD contributes the $\mathrm{C}(4)-\mathrm{C}(5)$ unit to the thiazole ring, while thio-compounds contribute the $\mathrm{S}(1)-\mathrm{C}(2)-\mathrm{N}(3)$ one. The thiazolinones were converted into new thiazolinone-diazabutadienes, 37, or hydroxyacetylthiazoles, 38, from which were prepared many different 4-substituted thiazoles, 39, and pyridothiazole derivatives, 40, respectively. 19,21,28,76,95-99 The reaction between DBD and 2-mercapto-thiazoline or oxazoline led to the spiro heterocycles, 41 (Scheme 13). ${ }^{74}$

The DBD, 1, react in different ways with dialkyl- or diarylthioureas, 42. By treatment of DBD with diarylthioureas in equimolar ratio, the iminothiazolines 43 and 44 resulted. By reaction of two equivalents of $\mathrm{DBD}$ with dialkylthioureas, the imino-thiazolidinones, 45, were obtained. Under basic conditions, these compounds gave imidazolidine-pyrroline, 46, and imidazolidine-pyrazoline systems $\mathbf{4 7}$, while under acidic conditions they led to the thiazolidinepyrroline system, 48 (Scheme 14). ${ }^{21}$

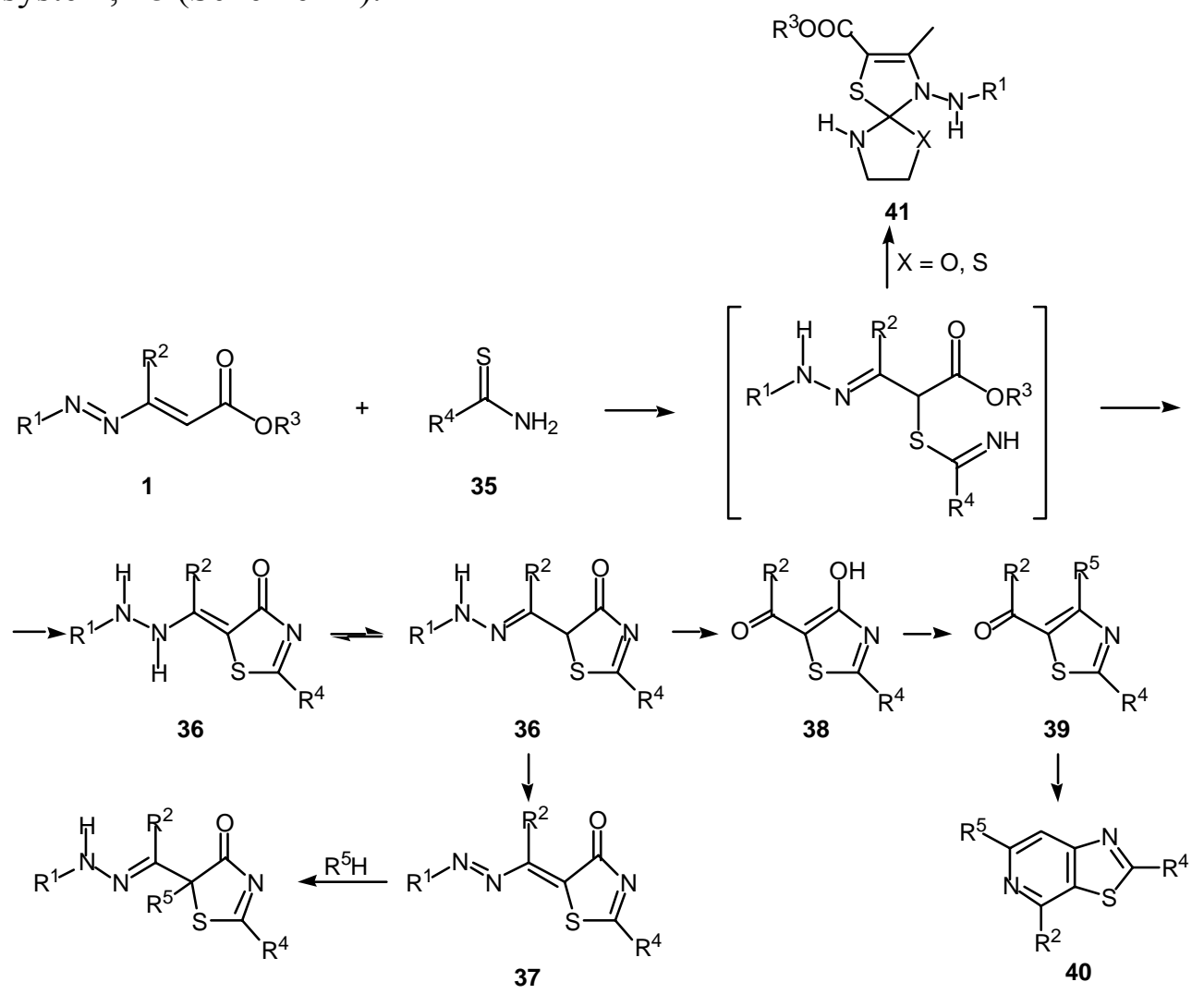

\section{Scheme 13}




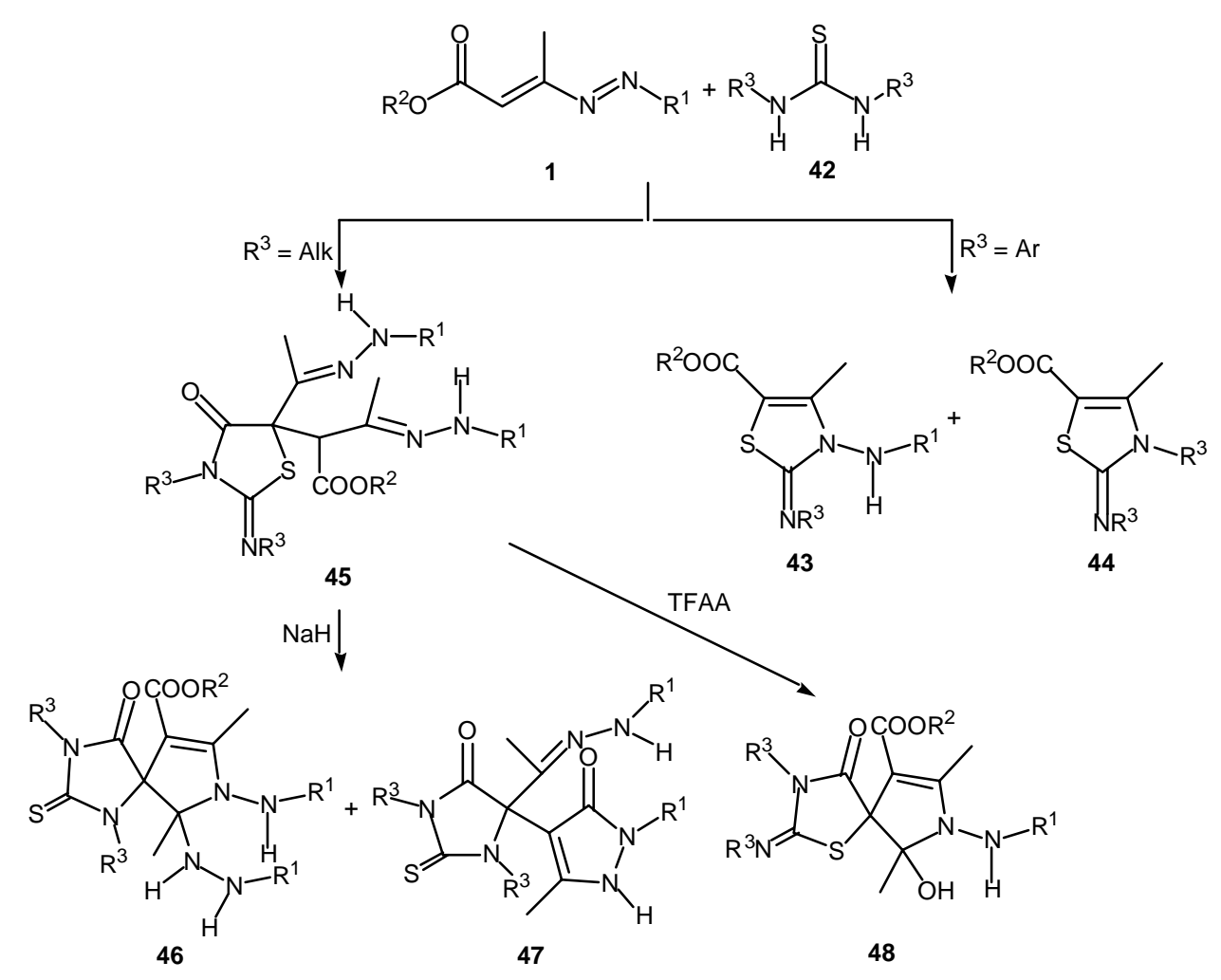

\section{Scheme 14}

The DBD, 1, react with seleno- amides or selenoureas, 49, in ways similar to the sulfur analogs. However, seleno-amides prefer the formation of hydrazinoselenazolines, 50, by attack of the imino nitrogen at the hydrazone carbon, while selenoureas prefer the formation of hydrazino-hydrazono selenazolinones, 52, by attack of the imino nitrogen at the ester group on the terminal carbon. Thus, two different [3+2] cyclizations take place in which the DBD furnish two different $\mathrm{C}(4)-\mathrm{C}(5)$ parts. The hydrazino-selenazolines were oxidized to the selenazoles, 51, while the hydrazino-hydrazono selenazolinones were converted into selenazolinonodiazabutadienes, 53, or added to a further DBD molecule to yield the adducts 54 and then the selenazoline-pyrroline systems, 55 (Scheme 15). ${ }^{24,25,45}$ 


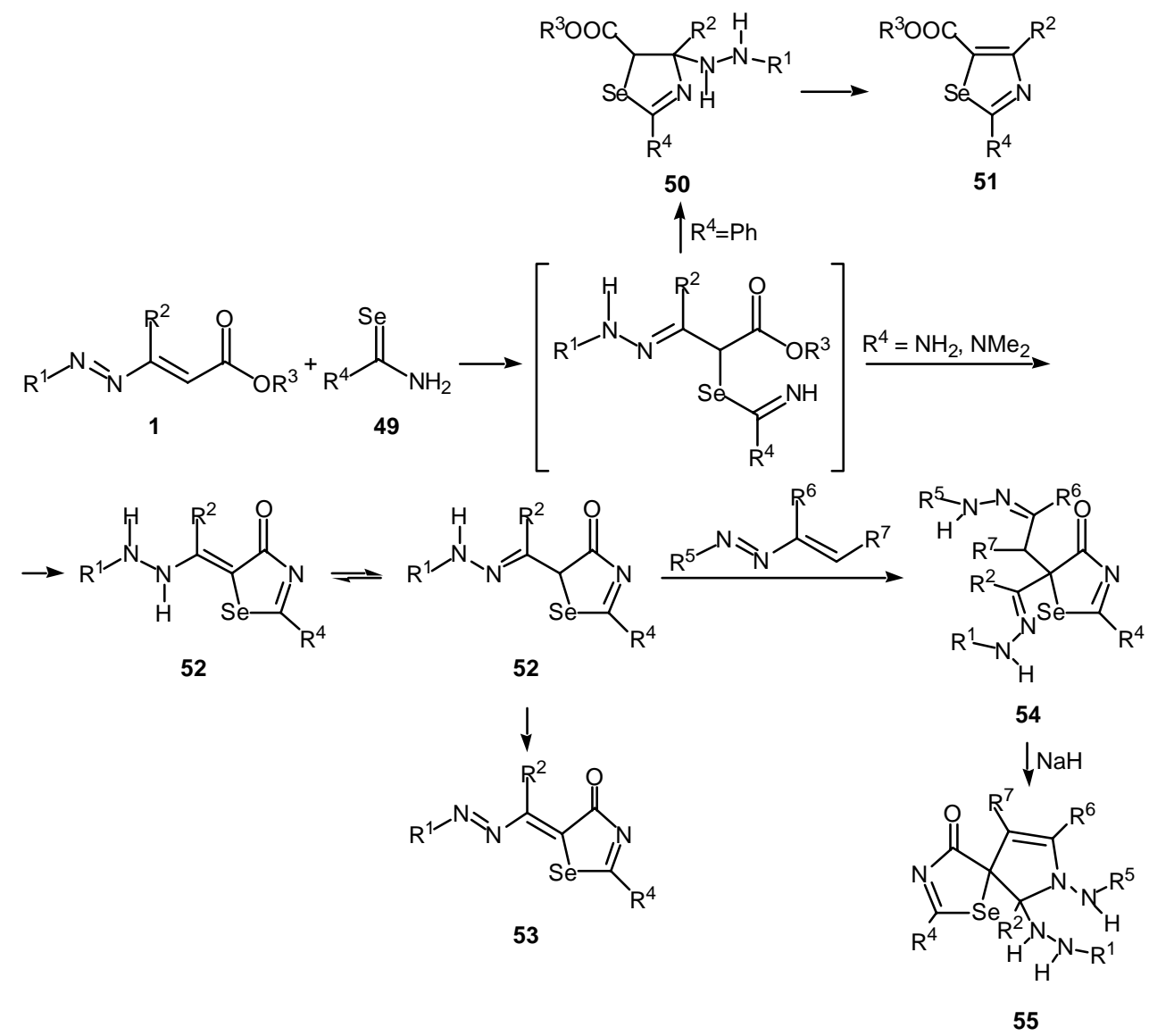

\section{Scheme 15}

$\alpha$-Functionalized hydrazones, $\mathbf{5 7}$, synthesized by conjugate addition of nucleophiles, $\mathbf{5 6}$, to the hetero-diene system of DBD, 1, produce 1,2,3-thiadiazoles or 1,2,3-selenadiazoles, 58, via the Hurd-Mori reaction (Scheme 16). ${ }^{44,45}$

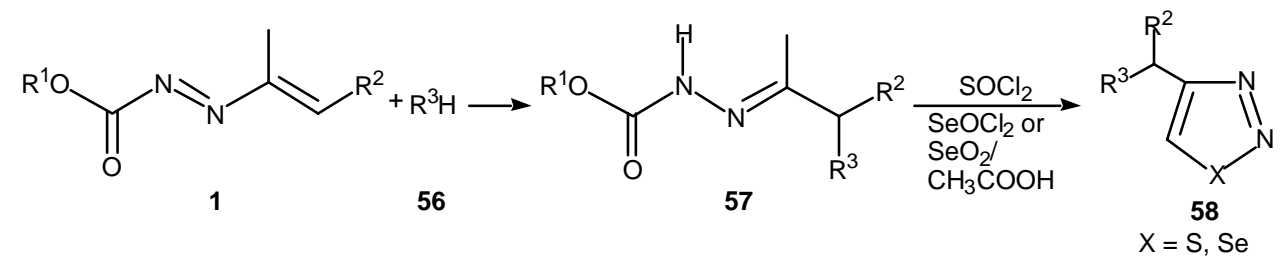

\section{Scheme 16}

Under basic conditions, amino-carbonyl-DBD, 1, react with $\beta$-di- or $\beta$-tricarbonyl compounds, 59, containing at least two keto functions to yield dihydropyridazines, $\mathbf{6 0}$, and then pyridazines, 61, by [4+2] annulations. The reaction of alkoxycarbonyl-DBD with the same reagents affords pyridazines by preliminary formation of cyclopropylpyrazolines through a complicated ring contraction-ring expansion mechanism. ${ }^{17,40}$ The treatment of DBD with halogeno- or nitro-malonates led to dihydropyridazin-6-ones 62 (Scheme 17).45,68 
Dihydropyridazines were also isolated in the reaction between DBD and 3-propargyl-1,2pentanedione, ${ }^{38}$ while the tetrahydropyridazines, 64, were prepared by "inverse-electrondemand" Diels-Alder reactions of aminocarbonyl-DBD 1, with electron-rich dienophiles, 63, in water (Scheme 18). ${ }^{100}$
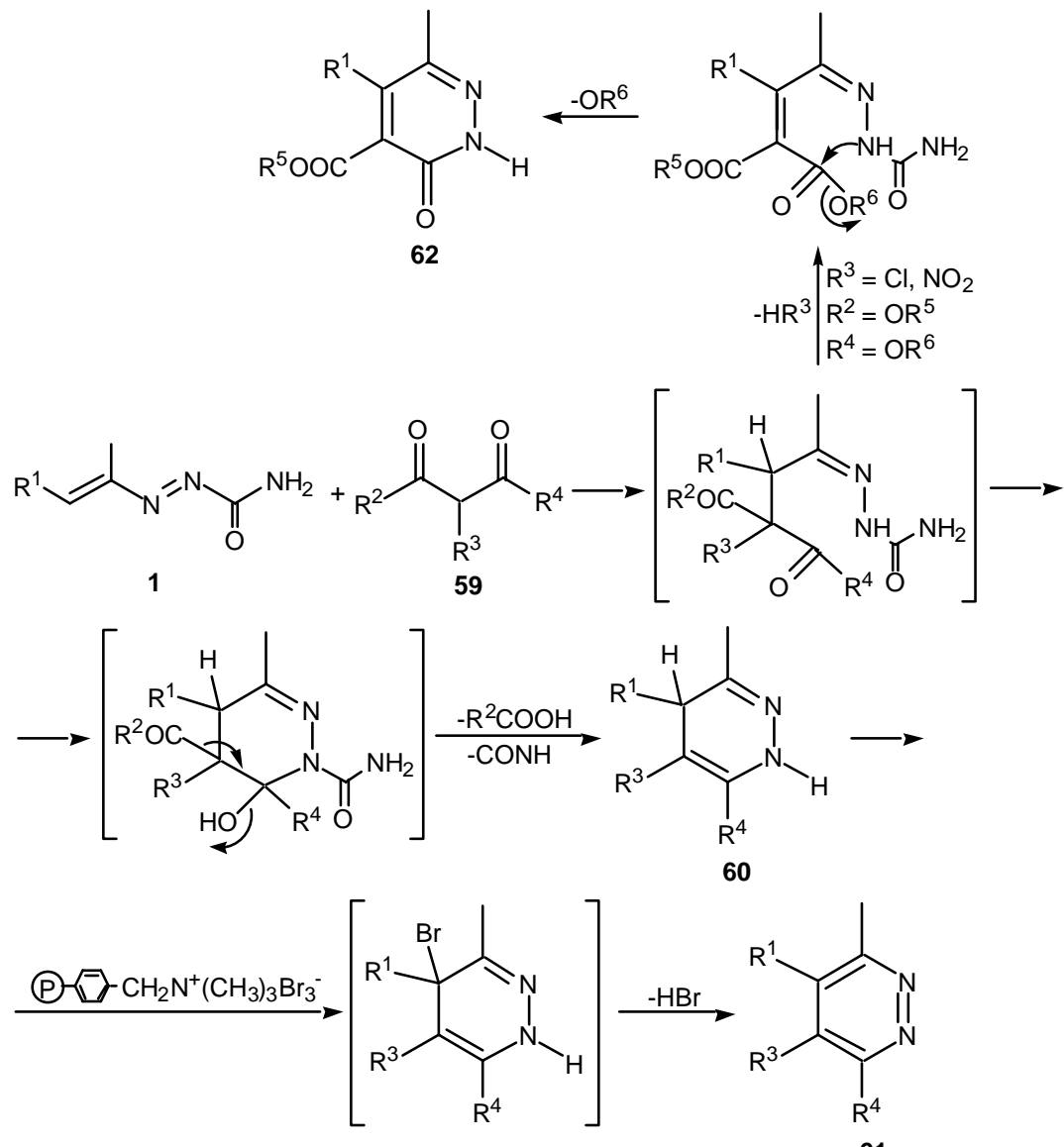

\section{Scheme 17}
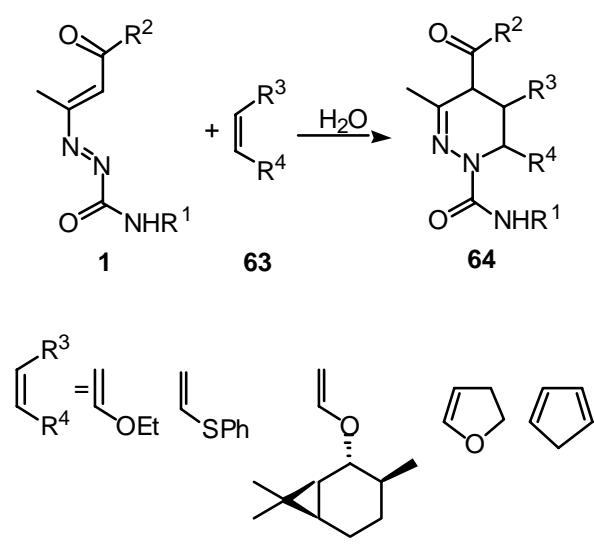

\section{Scheme 18}


The quinoxalines, 66, were obtained directly by treatment of $\mathrm{DBD}, \mathbf{1}$, with aromatic diamines, 65. The reaction probably proceeds through the preliminary 1,4-N-addition, intramolecular attack of the second nitrogen at the hydrazone carbon with consequent [4+2] cyclization, and final aromatization by oxidative loss of the hydrazine residue (Scheme 19). ${ }^{81}$

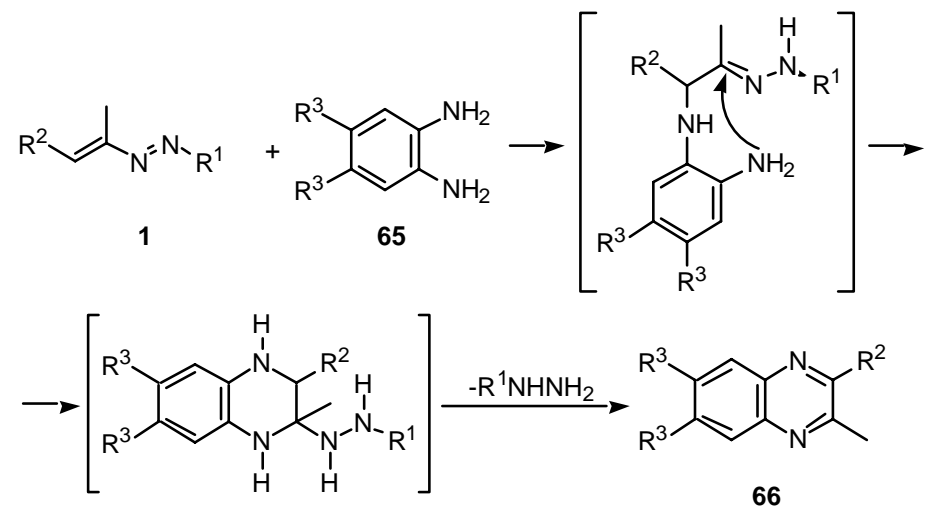

\section{Scheme 19}

Electron-poor hydrazines, $\mathbf{6 7}$, add chemo- and regio-selectively to electron-poor DBD, $\mathbf{1}$, to give the respective 1,4-adducts, 68. Under basic oxidative conditions, these adducts produce hydrazono-pyrazolinones, 69, while, under acidic oxidative conditions, they afford oxohydrazones, 70, and then triazinones, 71, by intramolecular attack of the semicarbazone amido group at the carbonyl one (Scheme 20). 85

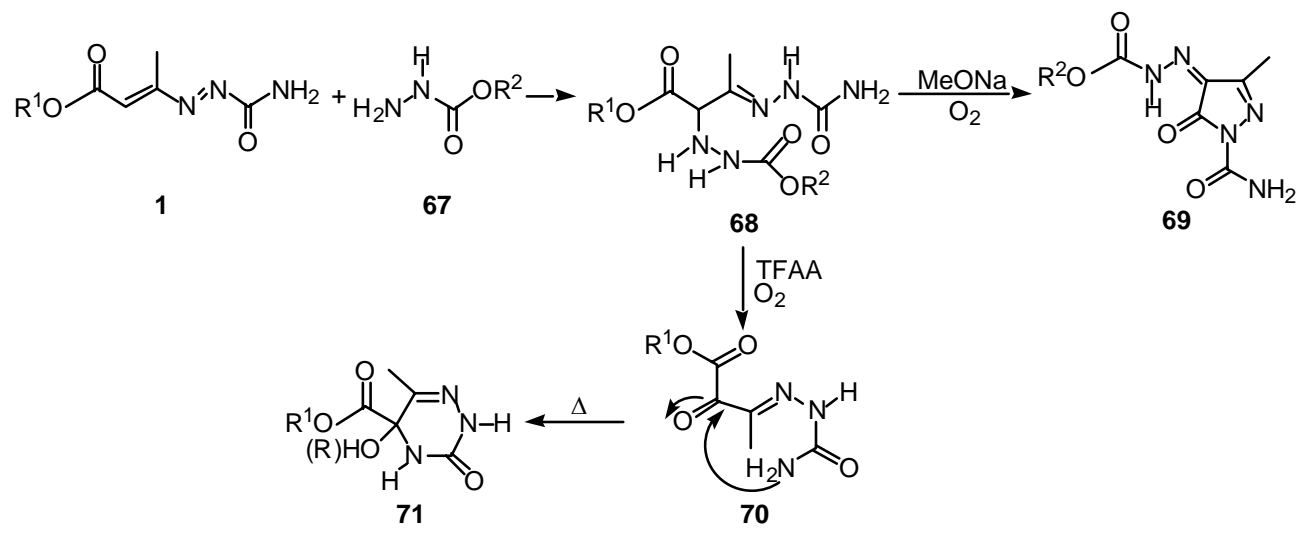

\section{Scheme 20}

Mixed and/or complex heterocyclic systems are shown in Schemes 7-9, 11, and 13-18, and are reported in pertinent papers. ${ }^{17,18,21-27,38,41-45,57,74,79,90,94,96,97,100}$ 


\section{Conclusions}

The ability of DBD as powerful nucleophilic acceptors, the flexibility with which they utilize the heterodiene system in different ways, and the electronic and reactivity roles played by the functional groups on the terminal carbon and nitrogen, make these compounds interesting products, and useful intermediates in organic, medicinal and agricultural chemistry.

Since they are no limits to human imagination, further creative developments in this field are presently in progress. Despite the activity over the past twenty-five years, our adventure with DBD is still continuing!

\section{Acknowledgments}

These investigations were supported by the Università di Urbino, CNR, and MIUR. The authors acknowledge all those who took part in these investigations.

\section{References}

1. Attanasi, O. A.; Caglioti, L. Org. Prep. Proced. Int. 1986, 18, 299.

2. Attanasi, O. A.; Filippone, P; Serra-Zanetti, F. Trends Heterocycl. Chem. 1993, 3, 461.

3. Attanasi, O. A.; Filippone, P.; Serra-Zanetti, F. Prog. Heterocycl. Chem. 1995, 7, 1.

4. Attanasi, O. A.; Filippone, P. Topics Heterocycl. Systems 1996, 1, 157.

5. Attanasi, O. A.; Filippone, P. Synlett 1997, 1128.

6. Attanasi, O. A.; Battistoni, P.; Fava, G. Can. J. Chem. 1983, 61, 2665.

7. Attanasi, O. A.; Battistoni, P.; Fava, G. Org. Prep. Proced. Int. 1983, 15, 1.

8. Attanasi, O. A.; Filippone, P.; Mei A.; Santeusanio, S. Synthesis 1984, 671.

9. Attanasi, O. A.; Filippone, P.; Mei A.; Santeusanio, S. Synthesis 1984, 873.

10. Attanasi, O. A.; Perrulli, F. R. Synthesis 1984, 874.

11. Attanasi, O. A.; Grossi, M.; Serra-Zanetti, F. Org. Prep. Proced. Int. 1985, 17, 385.

12. Attanasi, O. A.; Filippone, P.; Mei, A.; Serra-Zanetti, F. J. Heterocycl. Chem. 1985, 22, 1341.

13. Attanasi, O. A.; Filippone, P.; Guerra, P.; Serra-Zanetti, F. Synth. Commun. 1987, 17, 555.

14. Attanasi, O. A.; Grossi, M.; Mei, A.; Serra-Zanetti, F. Org. Prep. Proced. Int. 1988, 20, 408.

15. Attanasi, O. A.; De Crescentini, L.; Giorgi, R.; Perrone, A.; Santeusanio, S. Heterocycles 1996, 43, 1447.

16. Attanasi, O. A.; Filippone, P.; Fiorucci, C.; Mantellini, F. Gazz. Chim. Ital. 1997, 127, 201.

17. Attanasi, O. A.; Filippone, P.; Fiorucci, C.; Foresti, E.; Mantellini, F. J. Org. Chem. 1998, 63, 9880 . 
18. Attanasi, O. A.; De Crescentini, L.; Filippone, P.; Perrulli, F. R.; Santeusanio, S. Synlett 1999, 339.

19. Attanasi, O. A.; Filippone, P.; Guidi, B.; Perrulli, F. R.; Santeusanio, S. Heterocycles 1999, $51,2423$.

20. Attanasi, O. A.; Filippone, P.; Guidi, B.; Hippe, T.; Mantellini, F.; Tietze, L. F. Tetrahedron Lett. 1999, 40, 9277.

21. Attanasi, O. A.; Filippone, P.; Foresti, E.; Guidi, B.; Santeusanio, S. Tetrahedron 1999, 55, 13,423 .

22. Attanasi, O. A.; De Crescentini, L.; Filippone, P.; Guidi, B.; Perrulli, F. R.; Santeusanio, S. Synlett 1999, 1367.

23. Attanasi, O. A.; Filippone, P.; Fiorucci, C.; Mantellini, F. Chem. Lett. 2000, 984.

24. Attanasi, O. A.; Filippone, P.; Guidi, B.; Perrulli, F. R.; Santeusanio, S. Synlett 2001, 144.

25. Attanasi, O. A.; Filippone, P.; Perrulli, F. R.; Santeusanio, S. Eur. J. Org. Chem. 2002, 2323.

26. Attanasi, O. A.; Filippone, P.; Perrulli, F. R.; Santeusanio, S. Tetrahedron 2001, 57, 1387.

27. Attanasi, O. A.; De Crescentini, L.; Filippone, P.; Mantellini, F. New J. Chem. 2001, 25, 534.

28. Attanasi, O. A.; De Crescentini, L.; Filippone, P.; Mantellini, F.; Tietze, L. F. Tetrahedron 2001, 57, 5855.

29. Attanasi, O. A.; Bonifazi, P.; Foresti, E.; Pradella, G. J. Org. Chem. 1982, 47, 684.

30. Attanasi, O. A.; Bonifazi, P.; Buiani, F. J. Heterocycl. Chem. 1983, 20, 1077.

31. Attanasi, O. A.; Filippone, P.; Mei, A.; Santeusanio, S.; Serra-Zanetti, F. Synthesis 1985, 157.

32. Attanasi, O. A.; Perrulli, F. R.; Serra-Zanetti, F. Heterocycles 1985, 23, 867.

33. Attanasi, O. A.; Filippone, P.; Mei, A.; Serra-Zanetti, F. Synth. Commun. 1986, 16, 343.

34. Attanasi, O. A.; Filippone, P.; Mei, A.; Serra-Zanetti, F. J. Heterocycl. Chem. 1986, 23, 25.

35. Attanasi, O. A.; Grossi, M.; Serra-Zanetti, F.; Foresti, E. Tetrahedron 1987, 43, 4249.

36. Attanasi, O. A.; Filippone, P.; Guerra, P.; Serra-Zanetti, F. Heterocycles 1988, 27, 149.

37. Attanasi, O. A.; Santeusanio, S.; Serra-Zanetti, F. Gazz. Chim. Ital. 1989, 119, 631.

38. Arcadi, A.; Attanasi, O. A.; De Crescentini, L.; Rossi, E.; Serra-Zanetti, F. Tetrahedron 1996, 52, 3997.

39. Attanasi, O. A.; Filippone, P.; Fiorucci, C.; Mantellini, F. Tetrahedron Lett. 1997, $38,873$.

40. Attanasi, O. A.; Filippone, P.; Fiorucci, C.; Mantellini, F. Synlett 1997, 1361.

41. Attanasi, O. A.; Filippone, P.; Fiorucci C.; Mantellini, F. Tetrahedron Lett. 1999, 40, 3891.

42. Attanasi, O. A.; De Crescentini, L.; Filippone, P.; Mantellini, F. Synlett 2000, 955.

43. Attanasi, O. A.; Filippone, P.; Guidi, B.; Mantellini, F.; Santeusanio, S. Synthesis 2001, 1837.

44. Attanasi, O. A.; De Crescentini, L.; Filippone, P.; Mantellini, F. Synlett 2001, 557.

45. Attanasi, O. A. unpublished results.

46. Attanasi, O. A.; Santeusanio, S. Synthesis 1983, 742. 
47. Attanasi, O. A.; Grossi, M.; Serra-Zanetti, F. Org. Prep. Proced. Int. 1986, 18, 1.

48. Attanasi, O. A.; Filippone, P.; Mei, A.; Perrulli, F. R.; Serra-Zanetti, F. Synth. Commun. 1986, 16, 1411.

49. Attanasi, O. A.; Filippone, P.; Guerra, P.; Serra-Zanetti, F.; Foresti, E.; Tugnoli, V. Gazz. Chim. Ital. 1988, 118, 533.

50. Attanasi, O. A.; Filippone, P.; Mei, A.; Santeusanio, S.; Serra-Zanetti, F. Bull. Chem. Soc. Jpn. 1986, 59, 3332.

51. Attanasi, O. A.; Filippone, P.; Santeusanio, S.; Serra-Zanetti, F. Synthesis 1987, 381.

52. Attanasi, O. A.; Grossi, M.; Serra-Zanetti, F. J. Heterocycl. Chem. 1988, 25, 1263.

53. Attanasi, O. A.; Filippone, P.; Santeusanio, S. Tetrahedron Lett. 1988, 5787.

54. Attanasi, O. A.; Filippone, P.; Mei, A.; Bongini, A.; Foresti, E. Tetrahedron 1990, 46, 5685.

55. Attanasi, O. A.; Filippone, P.; Mei, A. J. Chem. Res. 1991, 252.

56. Attanasi, O. A.; Santeusanio, S.; Serra-Zanetti, F.; Foresti, E.; McKillop, A. J. Chem. Soc., Perkin Trans. 1 1990, 1669.

57. Attanasi, O. A.; De Crescentini, L.; Foresti, E.; Gatti, G.; Giorgi, R.; Perrulli, F. R.; Santeusanio, S. J. Chem. Soc., Perkin Trans. 1 1997, 1829.

58. Attanasi, O. A.; De Crescentini, L.; Santeusanio, S.; Serra-Zanetti, F.; McKillop, A.; Liao, Z. J. Chem. Soc., Perkin Trans. 1 1992, 1009.

59. Attanasi, O. A.; De Crescentini, L.; McKillop, A.; Santeusanio, S.; Serra-Zanetti, F. J. Chem. Soc., Perkin Trans. 1 1992, 3099.

60. Attanasi, O. A.; Liao, Z.; McKillop, A.; Santeusanio, S.; Serra-Zanetti, F. J. Chem. Soc., Perkin Trans. 1 1993, 315.

61. Attanasi, O. A.; Ballini, R.; Liao, Z.; Santeusanio, S.; Serra-Zanetti, F. Tetrahedron 1993, 49, 7027.

62. Attanasi, O. A.; Filippone, P.; Giovagnoli, D.; Mei, A. Synthesis 1994, 181.

63. Arcadi, A.; Attanasi, O. A.; Liao, Z.; Serra-Zanetti, F. Synthesis 1994, 605.

64. Attanasi, O. A.; Filippone, P.; Giovagnoli, D.; Mei, A. Synth. Commun. 1994, $24,453$.

65. Attanasi, O. A.; De Crescentini, L.; Foresti, E.; Serra-Zanetti, F. Can. J. Chem. 1994, 72, 2305.

66. Attanasi, O. A.; De Crescentini, L.; Favi, G.; Filippone, P.; Mantellini, F.; Santeusanio, S. Synthesis 2002, 1546.

67. Attanasi, O. A.; De Crescentini, L.; Filippone, P.; Gatti, G.; Mantellini, F.; Santeusanio, S. Tetrahedron 1998, 54, 7581.

68. Attanasi, O. A.; Ballini, R.; De Crescentini, L.; Filippone, P.; Mantellini, F. J. Org. Chem. 1999, 64, 9653.

69. Attanasi, O. A.; De Crescentini, L.; Favi, G.; Filippone, P.; Mantellini, F.; Santeusanio, S. J. Org. Chem. 2002, 67, 0000.

70. Attanasi, O. A.; Battistoni, P.; Fava, G. Synth. Commun. 1979, 9, 465.

71. Attanasi, O. A.; Battistoni P.; Fava, G. J. Org. Chem. 1981, 46, 447. 
72. Attanasi, O. A.; De Crescentini, L.; Filippone, P.; Foresti, E.; Galeazzi, R.; Ghiviriga I.; Katritzky, A. R. Tetrahedron 1997, 53, 5617.

73. Attanasi, O. A.; Foresti, E.; Liao, Z.; Serra-Zanetti, F. J. Org. Chem. 1995, 60, 149.

74. Arcadi, A.; Attanasi, O. A.; Guidi, B.; Rossi, E.; Santeusanio, S. Synlett 2000, 1464.

75. Attanasi, O. A.; Buratti, S.; Filippone, P.; Fiorucci, C.; Foresti, E.; Giovagnoli, D. Tetrahedron 1996, 52, 1579.

76. Attanasi, O. A.; De Crescentini, L.; Foresti, E.; Galarini, R.; Santeusanio, S.; Serra-Zanetti, F. Synthesis 1995, 1397.

77. Attanasi, O. A.; Filippone, P.; Battistoni, P.; Fava, G. Synthesis 1984, 422.

78. Arcadi, A.; Attanasi, O. A.; De Crescentini, L.; Rossi, E. Tetrahedron Lett. 1997, 38, 2329.

79. Abbiati, G.; Arcadi, A.; Attanasi, O. A.; De Crescentini, L.; Rossi, E. Angew. Chem. Int. Ed. 2002, 41, 1400.

80. Abbiati, G.; Arcadi, A.; Attanasi, O. A.; De Crescentini, L.; Rossi, E. Tetrahedron 2001, 57, 2031.

81. Attanasi, O. A.; De Crescentini, L.; Filippone, P.; Mantellini, F.; Santeusanio, S. Helv. Chim. Acta 2001, 84, 2379.

82. Arcadi, A.; Attanasi, O. A.; De Crescentini, L.; Rossi, E.; Serra-Zanetti, F. Synthesis 1996, 533.

83. Attanasi, O. A.; Santeusanio, S.; Serra-Zanetti, F. Synthesis 1994, 372.

84. Attanasi, O. A.; Santeusanio, S.; Serra-Zanetti, F. Org. Prep. Proced. Int. 1994, $26,485$.

85. Attanasi, O. A.; De Crescentini, L.; Filippone, P.; Foresti, E.; Mantellini, F. J. Org. Chem. 2000, 65, 2820.

86. Attanasi, O. A.; Filippone, P.; Mei, A. Tetrahedron 1992, 48, 1707.

87. Attanasi, O. A.; Buratti, S.; Filippone, P.; Giovagnoli, D. J. Chem. Res. 1994, 192.

88. Attanasi, O. A.; Filippone, P.; Giovagnoli, D. Org. Prep. Proced. Int. 1994, 26, 321.

89. Attanasi, O. A.; Filippone, P.; Fiorucci, C. Tetrahedron 1997, 53, 1467.

90. Attanasi, O. A.; Colombani, S. M.; De Crescentini, L.; Giorgi, R.; Monti, S.; Perrone, A.; Perrulli, F. R.; Renzetti, A. R.; Santeusanio, S. Farmaco 1999, 54, 64.

91. Attanasi, O. A.; Santeusanio, S.; Barbarella, G.; Tugnoli, V. Magn. Res. Chem. 1985, 23, 383.

92. Giuseppetti, G.; Tadini, C.; Attanasi, O. A.; Grossi, M.; Serra-Zanetti, F. Acta Cryst. 1985, C41, 450.

93. Attanasi, O. A.; Grossi, M; Perrulli, F. R.; Santeusanio, S.; Serra-Zanetti, F.; Bongini, A.; Tugnoli, V. Magn. Res. Chem. 1988, 26, 714.

94. Attanasi, O. A.; Liu, M. T. H.; Romashin, Y. N.; Nijjar, S. S. Chem. Commun. 2000, 1147.

95. Arcadi, A.; Attanasi, O. A.; De Crescentini, L.; Guidi, B.; Rossi, E.; Santeusanio, S. Gazz. Chim. Ital. 1997, 127, 609.

96. Arcadi, A.; Attanasi, O. A.; Guidi, B.; Rossi, E.; Santeusanio, S. Chem. Letter 1999, 59.

97. Arcadi, A.; Attanasi, O. A.; Guidi, B.; Santeusanio, S.; Rossi, E. Eur. J. Org. Chem. 1999, 3117. 
98. Attanasi, O. A.; Giorgi, G.; Guidi, G.; Salvini, L.; Santeusanio, S. J. Mass Spectrom. 2002, 37, 169.

99. Attanasi, O. A.; Filippone, P.; Giorgi, G.; Salvini, L.; Santeusanio, S. J. Mass Spectrom. 2002, 37, 709.

100.Attanasi, O. A.; De Crescentini, L.; Filippone, P.; Fringuelli, F.; Mantellini, F.; Matteucci, M.; Piermatti, O.; Pizzo, F. Helv. Chim. Acta 2001, 84, 513. 